\title{
A CONCEPT BASED MODEL FOR PRODUCT DEVELOPMENT IN THE EMERGING MARKET
}

\author{
Navdeep Singh Turna ${ }^{1}$, Tejwant Singh Grewal ${ }^{2}$ \\ ${ }^{1}$ Assistant Professor, Mechanical Engineering, Chandigarh University, Gharuan, Mohali \\ ${ }^{2}$ Assistant Professor, Mechanical Engineering, Chandigarh University, Gharuan, Mohali
}

\begin{abstract}
Emerging market like Asia and Africa are opening a big room of opportunities to do business. The companies which are already globally recognized have started acknowledging this issue and they are making their product and business strategies according to the user perceptions of these growing markets. In these markets where the bigger players are already present, how the local players and new companies can survive and harness the market profits in this competitive environment. This research work provides a conceptual model which can help the local and new companies in increasing their market share and profits within a short time period. This model listen's the voice of customer and it also accounts the market trend, while designing or planning a product. Multi-factor evaluation process (MFEP) is used in this product development model and an exploratory example of mobile product is also given to clarify the implementation of this model.
\end{abstract}

Keywords = Product technical specifications, New product development, Product design strategy, Voice of customer, Multi- Factor evaluation process (MFEP)

\section{INTRODUCTION}

The nascent market of Asia and Africa have become key attractions for the well known companies for doing business, because they know that they have global recognition in the form of quality, service and reliability so, they can easily settle down and increase their market share in these countries. But the consumers of these markets (countries) look for high value of product at lower cost. The bigger players spend a lot on the research, development, marketing and other activities to make their good image among consumers and to also grab the maximum share of these markets.

Now, the local companies are facing a huge challenge in their markets, they have less resources, low budget and their product design strategies are not strong as the bigger players. This research provides a 'NAV' model approach for designing the new products for local companies in a competitive environment. The model starts with the technical benchmarking or customer satisfaction benchmarking. The list of benchmarked companies and the benchmarked products are being prepared during this phase. The benchmarked preferences and priorities are also based on the user's opinion, user feedback and surveys. After finalizing the products, their technical specifications are benchmarked.

\section{LITERATURE REVIEW}

Many a studies are conducted to access the importance of customer support or customer interaction in new product development (NPD). (Goffin and New, 2001) found customer support an must have element for successful marketing of many products, The customer support requirements should be evaluated during NPD because a good product design can make customer support more efficient and cost effective (Armistead and Lark, 1992). Customer support plays an important role in increasing the probability of success of new products (Cooper and Kleinschmidt, 1993). (Milward and Lewis, 2005) identified the main barriers to the development of new products in small manufacturing companies in UK, In their research they found that the dominant behavior of the owner, more stress on time and cost than other factors and lack of understanding of importance of product design were the main barriers to new product development. (Gangurde and Akarte, 2012) proposed a multi-criteria decision making (MCDM) approach to evaluate product design alternatives in respect to the customer requirements, the mobile phone example had been used to demonstrate this approach. (Besharati, et al., 2006) has identified three factors, which according to them were the most important ones in deciding the final product configurations. These three factors were, market demand on the basis of customer's preferences, designer's preferences based on his experience, knowledge $\&$ skill and the last one was uncertainty in achieving the planned design performance. (Mazzoni et al., 2007) Identified three different categories of customers in mobile phone segment, naming as "basic user segment", "value driven segment" and "techno-fun user segment". The users were categorized on the basis of their demand for features. A crucial decision faced by many companies across the world is the selection of an optimal mix of product features to be offered in the target market. Fulfilling the customer's individual requirement through product design configurations is essentially an optimization problem (Jiao and Zhang, 2005). (Ostori and Bi, 2010) Proposed fuzzy models for finalizing the product configurations. Product 
features influence the user's intentions while they purchase a product (Seva et al., 2007). (Dacko, 2000), Studied that a majority of companies were followers of best in class or pioneering firms in new and related product markets. Managers of almost all the companies can avail the benefits from benchmarking their competitors. It costs high to first enter in the market and the followers can develop the product of same range at lower price by making an effective strategy considering all aspects related to the product development (Lieberman and Montgomery, 1991).

\section{CONCEPTUAL MODEL}

On the basis of examination of the extensive literature and scope of the present research, conceptual model have prepared and presented in figure 1. The proposed 'NAV' model is based on Quality function deployment (QFD) tool presented by Akao in 1972. This model is mainly focused on accounting the voice of customer in a competitive market, where bigger players or pioneering firms already exists. The model is completely defined with a flow chart. It starts with selection of goal, in this research paper an example of smartphone is also given, so with this example here our main aim is to make a smartphone which can survive in a competitive environment. Next is defining product category, for example smartphone, budget phone, and feature phone et cetera. The next step is defining the competitors at initial stage, so that the company can make their product accordingly in terms of quality and production. After selecting the competitors their products of same category and same range are taken into the account and their specification are benchmarked. Now we are having the information regarding each of our competitor's products of same range, this complete information is prepared in a form of data base. Now the key element voice of customer comes in the picture, the customer are asked their choices from all available benchmarked options to decrease the designing time and to increase the customer satisfaction. Company does a market analysis to know the current market scenarios' like importance of camera in smartphone and importance of ram in a Smartphone. According to the market analysis, company assigns weight to each individual specification. Then the customer also gave a priority value to the feature. For finding an optimum solution for the problem the company does MFEP analysis to select the best from the alternatives and also to take the voice of customer in context. The alternative getting highest final weight is selected for optimization. A complete MFEP analysis is defined in section 4 and 5 of this paper.

\section{RESEARCH METHOD}

Multi-factor evaluation process (MFEP) is a quantitative approach, for example, is recommended in cases where all of the important criteria can be assigned appropriate numerical weights and each alternative can be evaluated quantitatively in terms of these criteria (Render and stairs, 1994). According to (Diep, et al., 2006) MFEP consists of three steps:

Step 1: List all factors and assign every factor a weight between 0 and 1 ;

\section{$(0<F W a<1)$}

Step 2: Factor evaluation

With each factor a, we assess solution $b$ by giving it a Coefficient value FEab (called evaluation of solution b under factor a);

Step 3: Total weighted evaluation

$$
T W E \mathrm{~b}=\sum_{a} \mathrm{FWa} \times \mathrm{FEab}
$$

Considering the values of TWEb, the best solution is selected.

\section{A SMARTPHONE EXAMPLE}

With the MFEP, we start by listing the factors and their relative importance on a scale from 0 to 1 . Let's consider an example. A mobile company is looking at customer review for various functions of mobile to give full deliverance according to customer voice and compete in the market. Company has determined from market research that, the only four factors really are important according to customer preferences which are ram, camera, battery life and processor. Furthermore, company has decided that ram is the most important to their customer so they assigned it with a weight of 0.4 . What comes next is the camera with a weight of 0.3 , battery life is given an importance weight of 0.2 and the least importance has been given to processor by allocating the weight of 0.1 . Like any MFEP problem, the total sum of importance weights for factors must be equal to 1

Table-1 Factor Weight

\begin{tabular}{|l|l|}
\hline Factor name & Factor weight \\
\hline Ram & 0.4 \\
\hline Camera & 0.3 \\
\hline Battery life & 0.2 \\
\hline Processor & 0.1 \\
\hline Total & 1 \\
\hline
\end{tabular}

As a hypothetical case the company has asked 3 customers for each of these reviews regarding a Smartphone. The customer feedback is then evaluated by given them rating on a 0 to 1 scale. The customer $\mathrm{A}$ has given ram an evaluation of 0.9 , Camera of 0.5 , battery life of 0.7 and for processor 0.4. The customers B, given ram an evaluation of 0.7 , Camera of 0.4 , battery life of 0.6 and for processor 0.7 . The customers $\mathrm{C}$, given ram an evaluation of 0.9 , Camera of 0.8 , battery life of 0.9 and for processor 0.6

Table -2 Factor Evaluations

\begin{tabular}{|l|l|l|l|}
\hline $\begin{array}{l}\text { Factor } \\
\text { name }\end{array}$ & $\begin{array}{l}\text { CUSTOMER } \\
\mathrm{A}\end{array}$ & $\begin{array}{l}\text { CUSTOMER } \\
\mathrm{B}\end{array}$ & $\begin{array}{l}\text { CUSTOMER } \\
\mathrm{C}\end{array}$ \\
\hline Ram & 0.9 & 0.7 & 0.9 \\
\hline Camera & 0.5 & 0.4 & 0.8 \\
\hline $\begin{array}{l}\text { Battery } \\
\text { life }\end{array}$ & 0.7 & 0.6 & 0.9 \\
\hline Processor & 0.4 & 0.7 & 0.6 \\
\hline
\end{tabular}




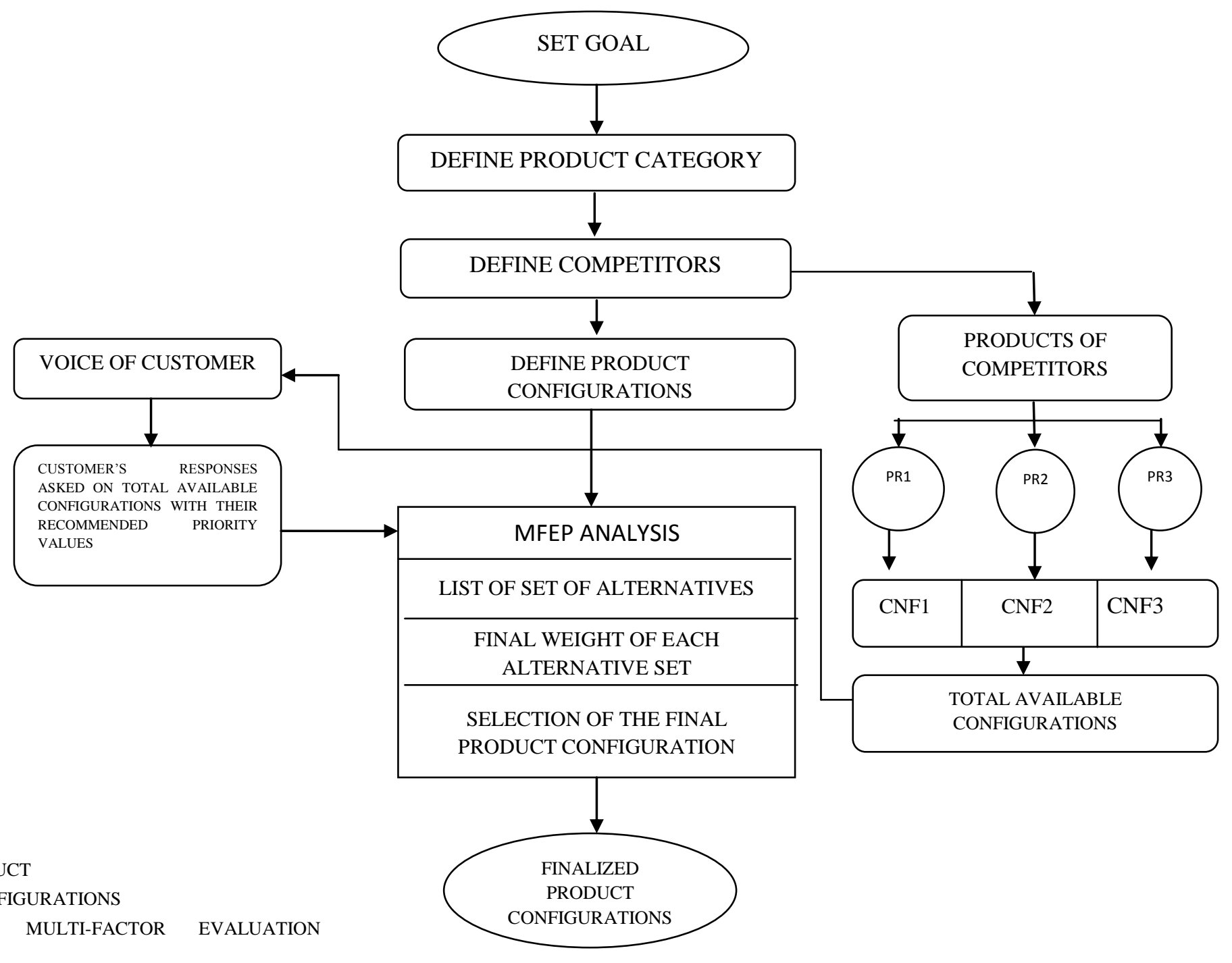

Fig -1 NAV Product Specification Model

After accessing the rating given by all three customers, the individual ratings are multiplied with factor weights assigned by the company. Given this information, company can determine a total weighted evaluation for each of the alternatives. Every customer is given a factor evaluation for the four factors, after accessing the rating given by all three customers; the individual ratings are multiplied with factor weights assigned by the company and summed to get a total weighted evaluation for each customer view.

Table -3 Evaluation of Customer- A

\begin{tabular}{|l|l|l|l|}
\hline $\begin{array}{l}\text { Factor } \\
\text { name }\end{array}$ & $\begin{array}{l}\text { Factor } \\
\text { weight }\end{array}$ & $\begin{array}{l}\text { Factor } \\
\text { evaluation }\end{array}$ & $\begin{array}{l}\text { Weighted } \\
\text { evaluation }\end{array}$ \\
\hline Ram & 0.4 & 0.9 & 0.36 \\
\hline Camera & 0.3 & 0.5 & 0.15 \\
\hline $\begin{array}{l}\text { Battery } \\
\text { life }\end{array}$ & 0.2 & 0.7 & 0.14 \\
\hline Processor & 0.1 & 0.4 & 0.04 \\
\hline Total & 1 & & 0.69 \\
\hline
\end{tabular}

Table -4 Evaluation of Customer- B

\begin{tabular}{|l|l|l|l|}
\hline $\begin{array}{l}\text { Factor } \\
\text { name }\end{array}$ & $\begin{array}{l}\text { Factor } \\
\text { weight }\end{array}$ & $\begin{array}{l}\text { Factor } \\
\text { evaluation }\end{array}$ & $\begin{array}{l}\text { Weighted } \\
\text { evaluation }\end{array}$ \\
\hline Ram & 0.4 & 0.7 & 0.28 \\
\hline camera & 0.3 & 0.4 & 0.12 \\
\hline Battery life & 0.2 & 0.6 & 0.12 \\
\hline processor & 0.1 & 0.7 & 0.07 \\
\hline & 1 & & 0.59 \\
\hline
\end{tabular}

Table -5 Evaluation of Customer- C

\begin{tabular}{|l|l|l|l|}
\hline $\begin{array}{l}\text { Factor } \\
\text { name }\end{array}$ & $\begin{array}{l}\text { Factor } \\
\text { weight }\end{array}$ & $\begin{array}{l}\text { Factor } \\
\text { evaluation }\end{array}$ & $\begin{array}{l}\text { Weighted } \\
\text { evaluation }\end{array}$ \\
\hline Ram & 0.4 & 0.9 & 0.36 \\
\hline camera & 0.3 & 0.8 & 0.24 \\
\hline Battery life & 0.2 & 0.9 & 0.18 \\
\hline processor & 0.1 & 0.6 & 0.06 \\
\hline & 1 & & 0.84 \\
\hline
\end{tabular}




\section{RESULTS}

After observing the results it can be said that, customer A has received a total weighted evaluation of 0.69 . The same type of analysis is done for customer B and C. The customer $\mathrm{C}$ has received the highest total weighted evaluation of 0.84 ; A was next, with a total weighted evaluation of 0.69 and B got 0.59 . Using the multifactor evaluation process, company's decision should be to go with customer C, because it got the highest total weighted evaluation.

\section{REFERENCES}

[1] Akao, Y., (1972), New product development and quality assurance deployment system (in Japanese), Standardization and Quality Control 25 (4), 243-246

[2] Armistead, C.G. and Clark, G. (1992), Customer Service and Support, Pitman, London

[3] Besharati, B., Azarm, S. and Kannan, P.K. (2006), A decision support system for product design selection: a generalized purchase modeling approach, Decision Support Systems, Vol. 42 No. 1, pp. 333-350

[4] Cooper, R.G. and Kleinschmidt, E.J. (1993), Major new products: what distinguishes the winners in the chemical industry, Journal of Product Innovation Management, Vol. 10 No. 2, 90-111

[5] Dacko, S.G., (2000). Benchmarking competitive responses to pioneering new product introductions, Benchmarking: An International Journal, Vol. 7 No. 5, 2000, pp. 324-342

[6] Diep, N.N., Lee, S., Lee, Y. K. and Lee, H., (2006), Contextual Risk-based Access Control, IITA (Institute of Information Technology Advancement) (IITA-2006-(C1090-0602- 0002))

[7] Gangurde, S.R., and Akarte, M.M., (2012), Customer preference oriented product design using AHPmodified TOPSIS approach, Benchmarking: An International Journal Vol. 20 No. 4, 2013 pp. 549-564

[8] Goffin, K. and New, C., (2001). Customer support and new product development - An exploratory stud, International Journal of Operations \& Production Management, Vol. 21 No. 3, 275-301

[9] Jiao, J. and Zhang, Y. (2005), Product portfolio planning based on customer-engineering interaction, IIE Transaction, Vol. 37 No. 9, pp. 801-814.

[10] Lieberman, M.B. and Montgomery, D.B. (1991), Strategy of market entry: to pioneer or follow? in Glass, H.E. (Ed.), Handbook of Business Strategy, 2nd ed., Warren, Gorham, and Lamont, Boston, MA.

[11] Mazzoni, C., Castaldi, L. and Addeo, F. (2007), Consumer behavior in the Italian mobile telecommunication market, Telecommunications Policy, Vol. 31 No 10/11, pp. 632-647

[12] Milward, H. and Lewis, A., (2005). Barriers to successful new product development within small manufacturing companie, Journal of Small Business and Enterprise Development, Vol. 12 No. 3, 379-394

[13] Ostrosi, E. and Bi, S.T. (2010), Generalized design for optimal product configuration, International Journal of Advanced Manufacturing Technology, Vol. 49 No 1-4, pp. 13-25
[14] Render, B. \& Stair, R. M., Jr. (1994), Quantitative Analysis for Management, USA: Prentice-Hall, Inc

[15] Seva, R.R., Duh, H.B. and Helander, M.G. (2007), The marketing implications of affective product design, Applied Ergonomics, Vol. 38 No. 6, pp. 723731

\section{BIOGRAPHIES}

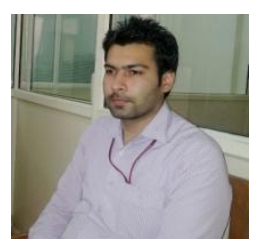

Mr. Navdeep Singh is working as Assistant Professor in Mechanical Engineering Department at Chandigarh University, Gharuan, Mohali (Punjab). $\mathrm{He}$ has obtained his Masters of Engineering in Production \& Industrial Engineering from Thapar University, Patiala. His area of research is new product development and business process integration (BPI).

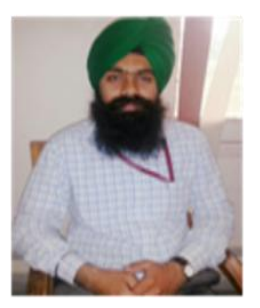

Mr. Tejwant Singh is working as Assistant Professor in Mechanical Engineering Department at Chandigarh University, Gharuan, Mohali (Punjab). He has obtained his M-Tech in Mechanical Engineering from Punjabi University, Patiala. His area of research is analysis of sensitization in stainless steel and product development 